\title{
Learning in Place: The Teaching Archivist and Place-Based Education
}

\author{
By Carey Beam and Carrie Schwier
}

ABSTRACT: Place-Based Education (PBE) uses students' local environments, communities, resources, and people to provide immersive learning opportunities. This educational approach advantages students' interest with the familiar to engage in more meaningful learning, develop stronger connections to their communities, and heighten their appreciation for their surroundings (both physical and cultural). Instructional archivists at higher education institutions often encounter the power of place commonly referred to in PBE literature. By explaining the foundation of this teaching method, its strengths and potential weaknesses, and PBE case studies featuring the university archivist and house museum director at Indiana University, this article explores PBE in the context of using campus archival collections for instructional purposes.

\section{Introduction}

Since Hugh A. Taylor's call for "Turning Undergraduates Loose in the Archives" at the 1971 Society of American Archivists annual meeting, ${ }^{1}$ much has been written about the value of integrating primary sources into the classroom. Over the last two decades, the majority of literature produced from an archival perspective predominantly focused on four main areas: establishing the role of the archivist in instruction, ${ }^{2}$ defining learning objectives,${ }^{3}$ assessing impact and learning outcomes,${ }^{4}$ and pedagogical theory. Furthermore, case studies documenting what instruction sessions and course collaborations look like on the ground abound in professional journals such as American Archivist; RBM: A Journal of Rare Books, Manuscripts, and Cultural Heritage; and the Journal of Archival Organization, and in recent edited volumes such as Past or Portal? Enhancing Undergraduate Learning through Special Collections and Archives; Using Primary Sources: HandsOn Instructional Exercises; and Educational Programs: Innovative Practices for Archives and Special Collections. ${ }^{5}$

Missing, however, is a grounding in pedagogical theory inextricably tied to the local primary sources that form the foundations of most archival collections. Given that, on an almost daily basis, instruction archivists utilize primary sources bound to their local communities in the classroom, the Place-Based Education model of teaching is an intuitive approach in these scenarios worthy of further discussion. This article provides the absent pedagogical theory, defines and contextualizes a brief history of Place-Based Education, and discusses two case studies of PBE applied to archival instruction.

\section{The Pedagogical Landscape}

As Magia Krause reported in 2008, 66.3 percent of repositories (including college/university archives, special collections, government archives, corporate archives, religious 
archives, museums, public libraries, and historical societies) reported offering more than five instruction sessions during the previous year. Most commonly, these sessions targeted undergraduates (75.6 percent), with 100 percent of college and university archives and 89.1 percent of special collections teaching this user group. ${ }^{6}$ Despite this prevalence, Krause also notes that the majority of archivists and special collections librarians who teach are "self-taught" instructors and only 10 percent have an education degree. ${ }^{7}$ Authors such as Sammie Morris, Tamar Chute, and Ellen Swain acknowledge that "archivists are not systematically trained to teach as part of their graduate study programs and may be unfamiliar with current pedagogical techniques. ..." Similarly, Kate Theimer notes that instruction "often benefits from a background in pedagogy, but most archivists lack any formal training in how to best structure educational experiences and simply forge ahead as best they can." Most recently, in their study of graduate archival coursework, Lindsay Anderberg, Robin Katz, Shaun Hayes, Alison Stankrauff, Morgen MacIntosh Hodgetts, Josué Hurtado, Abigail Nye, and Ashley Todd-Diaz found little pedagogical training for students. This is despite the fact that their survey of job postings between 2014 and 2017 demonstrated that "teaching" as a job requirement has increased dramatically. ${ }^{10}$

With so many archivists teaching, it is useful for them to remain cognizant of the many variables that inform archival instruction so they can leverage this knowledge within the classroom. Simply put, pedagogy is the science of teaching, and it considers and recognizes the numerous variables that inform instruction, such as teacher training and personal attributes, the various facets of environment, and students' needs and understandings. It can be daunting to consider the historical, psychological, and sociological elements that enter into the teaching and learning environment on any given day. While pursuing an additional degree in education might prove valuable, the majority of instructional archivists do not have the resources to do so. Thankfully, however, numerous continuing education opportunities in the form of workshops and online resources are also options. For the benefit of archivists' instructional collaborators and students, archivists should inform themselves of dominant learning theories and evidence-based teaching strategies. In addition, archivists already teaching are, consciously or not, employing teaching methods. Archivists educating themselves about the histories of those methods, the understood strengths and weaknesses of various teaching models, and the types of students, content, or learning objectives best suited to them will advance their critical role as educators. Fortunately, numerous resources are available.

Discussions of pedagogical theory abound in archival literature of the last two decades. Several cite the foundational 1998 Boyer Commission Report on Reinventing Undergraduate Education sponsored by the Carnegie Foundation that outlined 10 recommendations for "the radical reconstruction of undergraduate education at research universities." these, the recommendations calling for a focus on inquiry-based learning and involving students in the research process pose obvious possibilities for use in archival instruction. Authors focused in on this approach and on a related shift toward active-learning techniques. As Morgan Daniels and Elizabeth Yakel state, primary source research is "a natural way for humanities majors to participate in learning as inquiry as educators 
seek to teach students how to think historically and critically about sources." ${ }^{12}$ For others such as David Mazella and Julie Grob, the method is a perfect opportunity to move beyond the traditional show-and-tell approach:

The curiosity expressed by students when encountering primary source materials makes special collections instruction a natural fit for inquiry-based teaching. Without prompting, students become inquisitive. . . Students who customarily read annotated texts and secondary sources are now confronted with unmediated primary source objects that they must interpret. They begin to make connections to other content they have assimilated in the course or to issues and attitudes of the present day. With guidance from the faculty member, they begin to formulate research questions and interrogate subjects that have caught their interest. The rare book or handwritten diary has progressed from being an object of curiosity to a springboard for inquiry. ${ }^{13}$

Similarly, the dramatic and almost complete shift toward active-learning techniques in the classroom is well documented in the literature. Authors such as Magia Krause have eloquently traced the term's roots. ${ }^{14}$ In the introduction to their edited volume of case studies, Anne Bahde, Heather Smedberg, and Mattie Taormina provide this description:

... true active learning involves an inductive method of inquiry and student activities that lead to a clear understanding of key concepts. In the active learning classroom, learners fashion their own meanings by playing with concepts and discovering new knowledge, building on their prior knowledge as they compare, interrogate, and challenge ideas. ... Genuine active learning takes on meaning for students when it is developed through authentic tasks that stimulate those that will be required for an assignment, or in real life. ${ }^{15}$

\section{Sense of "Place"}

The final Boyer report recommendation to "Cultivate a Sense of Community," which calls for universities "to foster a community of learners" and "create a sense of place," is absent from the archival instruction literature. ${ }^{16}$ While instructional archivists use many methods, including those mentioned above, in a university archives setting, creating a sense of place cannot be separated from what archivists do. The theories behind this concept of place are already subtly evident in literature written by university archivists pertaining to outreach initiatives; however, they have yet to be applied to a specific pedagogical theory. In her 2000 article, Tamar Chute posited, "creating programs that increase student awareness of the archives may enrich" and "foster students' curiosity and interest in their surroundings." ${ }^{17}$ John Thelin noted in 2009, "educational institutions that preserve, make known, and promote their history create a strong and lively institutional identity. This identity can be shaped and boosted through documenting history, traditions, campus buildings, and campus personalities as well as through the variety of materials collected by archivists." ${ }^{18}$ More recently, others such as Jason Speck 
suggest that campus stories backed up by documentation in the archives have the opportunity to connect students with the history of their campus and

create strong attachments that last long after those students become alumni. . . . Every campus possesses a myriad of these kinds of tales, from the spooky ghost stories told each Halloween to the most infamous campus pranks. Each is a touchstone, a way of harkening back to a different time, linking the campus community of today to that of yesterday. They can become a source of cohesion among generations and illuminate a past that is often very different, providing a window into how much a campus has changed over time. ${ }^{19}$

Whether intentional or not, each of these authors hints at the multidisciplinary concept of "place." By no means a new concept, Frank Vanclay defines it as “'space' imbued with meaning. . . . Place, therefore, is the coming together of the biophysical, social and spiritual worlds. Simply put, place is space that is special to someone. The personal meaning that turns space into 'place' become embedded in people's memories and in community stories." ${ }^{20}$ Jeff Malpas traces the historic multidisciplinary threads of the concept, noting, "it is an idea that has both a long ancestry over the centuries and a wide currency across cultures." ${ }^{21}$ This then recurs in art and literature, philosophical inquiry, psychology, belief, and more. For Malpas, this diversity across cultures and disciples demonstrates that "place" is inextricably tied to human identity. ${ }^{22}$

Within the context of the university, this concept of "place" translates to the built environment and greenspaces of our campuses and local communities, to the historic figures and alumni associated with these spaces, and to the associated traditions and legends that give each their flavor. These are what make every campus and community unique.

\section{Place-Based Education}

The college and university archives' mission, collections, and location affords it the opportunity to leverage the strengths of the Place-Based Education (PBE) model of teaching, particularly to "Cultivate a Sense of Community" as recommended by the Boyer report. PBE employs local spaces, community members, and cultural heritage as primary learning resources. Leaders in this methodology, David Sobel and Gregory Smith, provide this commonly held definition: Place-based education is learning that is rooted in what is local - the unique history, environment, culture, economy, literature, and art of a particular place. This local focus has the power to engage students academically, pairing real-world relevance with intellectual rigor, while promoting genuine citizenship and preparing people to respect and live well in any community they choose. ${ }^{23}$

Fundamental to PBE is acknowledging its basis on the work of early twentieth-century social reformer and educator John Dewey. ${ }^{24}$ His philosophy of education extolled the value of experiential learning. Dewey saw the isolation of students from community in the US educational system as an unnatural approach to student learning. He promoted hands-on, interdisciplinary, and democratic (student-centered) learning. In addition to 
place-based learning, his teachings underpin other progressive learning strategies, such as project-based learning and service learning, often used in conjunction with $\mathrm{PBE}$.

Through the use of the college and university collections, instructional archivists instinctually incorporate local knowledge, history, and culture into their instruction and assignments. They immerse students in place through campus history, providing uniquely local educational resources and anticipating engagement as students find relevance in the materials put before them. Instructional archivists provide direct, active-learning opportunities through the handling of primary materials, the evaluation of a variety of formats, and transcription exercises. In addition, they facilitate learning outcomes and primary source literacy skills transferable to future research projects and, in many cases, future careers. By definition, archivists on campuses of higher education are place-based and poised to enrich students' learning and sense of community through the PBE model.

\section{History of Place-Based Education}

The aforementioned definitions of PBE are outgrowths of the concepts articulated in the 1990s by the Orion Society in its publication, Orion, as well as by Dr. John Elder of Middlebury College, who edited an anthology of stories about environmental placebased education. ${ }^{25}$ Both the Orion Society and Dr. Elder recognized the value of experiential learning as put forth by Dewey and were early leaders in promoting the benefits of immersing students in the natural world. Originally formalized in environmental education, PBE methodology evolved into a tool for rural school reform in the 1990s. Since that time, it has been extended to a variety of subjects in K-12 (history, math, English, and art education) and has been widely implemented in urban schools. ${ }^{26}$ In 2004, David Sobel published Place-Based Education: Connecting Classrooms E Communities, in which he expounds the value of place-based learning beyond eco-literacy-to civic engagement, community building, and inclusiveness. In their 2010 book, Gregory A. Smith and David Sobel propose reframing PBE to include more than local places and environment. ${ }^{27}$ They extoll its strength across the disciplines and present examples of its incorporation into the arts, diversity education, social justice, math, and history.

At the college level, a parallel trajectory emerges for PBE, from its being primarily employed by ecological studies to its eventual expansion into a broad swath of academic disciplines. In response to industrial development and laws related to the impact of its growth on agriculture and natural resources, schools began offering conservation courses in the late nineteenth and early twentieth centuries. By the 1960 s, conservation courses expanded and evolved into environmental education, a discipline rooted in the knowledge of the biophysical environment, its problems, and the means to solve them. ${ }^{28}$ As globalization intensified its demand on environmental health and natural resources, related studies in the areas of sustainability, eco-literacy, and eco-justice increasingly focused on the sociopolitical implications of restoration of the local. More recently, in 2003, David Gruenewald proposed a "critical pedagogy of place," a merger of critical pedagogy (a teaching approach inspired by critical theory that questions dominate narratives and sociopolitical structures) and PBE. Critical pedagogy of place acknowledges 
the interdependence of critical theory and local, immersive learning. Gruenewald states that Place-Based Education positively contributes to the well-being of the spaces that people inhabit, and critical theory is necessary to challenge assumptions and practices taken for granted by the dominant culture in those spaces. ${ }^{29}$

The convergence of the two methodologies into a single critical pedagogy of place serves as a reminder of the numerous and multidimensional variables in teaching. PBE can appear relatively straightforward if regarded as simply teaching in or about a local space or community, but it has complex implications. Contemporary philosopher of space and place Edward S. Casey encourages a broader understanding of "place" itself, inclusive of culture, gender, class, race, and ethnicity as critical dimensions of our experience of the local. ${ }^{30}$ Similar complexities hold true for the primary source literacy skills and understandings imparted in the vast majority of archival instruction. In its introduction to Guidelines for Primary Source Literacy, the ACRL SAA/RMBS Joint Task Force cautions that, like teaching methodologies, "literacies" related to primary materials and archival research do not exist independent of other models. Primary source literacy overlaps and intersects with visual, digital, and information literacies, and they are all subject to the influence of dominant culture and narratives, collective memory, historic interpretation, and individual perspectives. ${ }^{31}$

The Joint Task Force Guidelines provide direction as archivists navigate the complex world of primary source instruction, and teaching models frame pedagogical perspective in archives. As archivists become more familiar with the variety of teaching methods available, they can consciously choose the appropriate method(s) (or aspects thereof) to catalyze conversations and collaborations with faculty. For example, the notion that place (environments, structures, and communities) is subject to broader cultural, political, and economic forces finds a companion in archival principles. Historical context, power, agency, mediation, and gaps or absences shape existing primary documents and collections at repositories. The stories of a place or community are as much about the missing voices as about those that are preserved. Collections at colleges and universities have the potential to foster a sense of community in students through the history and heritage of their campuses and the lives of former students. Acknowledging the sociopolitical forces on the development of both the campus and the related preserved documents provides a space for dialogue and community building among students who may not see themselves represented within the collections.

Though still relatively rare, some noteworthy contributions to PBE's application in higher education exist in the literature. Place-Based Education in the Global Age, edited by David A. Gruenewald and Gregory A. Smith, is one such example. ${ }^{32}$ John I. Cameron's essay in that volume discusses the evolution of his "Sense of Place" courses, which use place as a subject of "teaching and inquiry." Over time, he moves from an emphasis on connecting students to a particular natural local environment to a realization that "the way to strengthen the experiential element of my teaching was to base it on . . . a place in the students' own locality." ${ }^{33}$ After he began to "experience the power of inhabitation," he redesigned the course and stated, "The new element transformed the class." ${ }^{4}$ 
Allowing students to choose their subject at the outset gave them the opportunity to immediately reflect upon or make meaning of their selections. Cameron builds on the strength of PBE as student-centered, focusing the course on their local environment as well as providing students the authority to choose a particularly relevant space within it.

College and university archivists using a variety of primary materials are familiar with the impact choice has on student engagement. Some students are drawn to old student photographs, some fascinated by faculty correspondence or campus policy, while others regard university yearbooks or campus architectural renderings with intense interest. This seemingly simple instructional method takes advantage of one of the primary strengths of PBE: relevancy to students. Like Cameron, archivists may invite reflection upon the choice itself, through either a discussion or writing assignment exploring the appropriateness of students' primary documents to their purposes, thus fostering a critical approach to the initial inquiry stage of research.

PBE leverages the power of place, taking advantage of student interest and personal motivation to create immersive and meaningful learning experiences. It provides evidence of deeper work quality that assumes greater meaning for each student. ${ }^{35}$ Initially sought to develop interest and health in the biophysical local environment, PBE is increasingly finding a role in civic engagement and investment in local economic and cultural environments. ${ }^{36}$ Place-based learning strengthens students' connections to their communities, their regions, and the other people in those environments. If these are the broader implications of $\mathrm{PBE}$, it is certainly likely that embedding students in learning about "their place"- their campus history and heritage-could cultivate a stronger sense of connection and community to their local campus environment, thus reinforcing Thelin's argument that archives can create a strong institutional identity.

\section{Advantages and Critiques of Place-Based Education}

Applying PBE to primary source instruction has advantages and limitations. Eric L. Ball and Alice Lai explore both in their 2006 article, covering the evolution of placebased pedagogy from its eco-humanist beginnings to Gruenewald's incorporation of critical theory, and examine its primary strengths and limitations. ${ }^{37}$ Academic archivists can draw parallels to critically frame primary source instruction through place-based teaching models.

Founded on the principle that linking students to their local environments and communities makes learning meaningful to their studies and their lives, PBE inspires interest, motivates rigorous study, and encourages deeper inquiry. Ideally, it places learning in what John Dewey referred to as "life terms" by using what is "already seen and felt and loved" by learners. ${ }^{38}$ College and university archivists experience this power of place when using campus primary sources - when students recognize their favorite campus hangouts in historic photographs, when they identify with a student who wrote of homesickness in his diary more than a hundred years ago, or when they empathize with the students marching on campus for justice just decades ago. More than likely, most 
archivists in institutions of higher education have witnessed the intensity with which these connections can induce deep learning experiences. Curiosity is heightened, questions abound, and often this interest leads to enhanced research in the archives or on the topic in general.

However, PBE's strength can also be its weakness. Ball and Lai astutely point out that place-based pedagogies assume that the local is meaningful to students. Local or familiar does not necessarily mean that it is particularly significant to a student. Furthermore, they go on to remind readers that students are subject to the same forces of globalization as are communities. They are exposed to "mass media, mass pop culture and the Internet," all of which may be more familiar than local politics, environmental health, or socioeconomic dynamics. ${ }^{39}$ Academic archivists also encounter students who find little connection to campus history and are seemingly uninspired by the primary materials put before them. There are many reasons for this. On the college or university campus, students' experiences are potentially more self-serving than immersive, focusing on coursework and future plans more than on campus culture or school spirit. Perhaps they are commuter students, nontraditional students with work and family obligations offcampus, or students who do not see themselves reflected in campus culture or history. In these cases, when the school itself holds little meaning, the institution's primary sources may be the gateway to inspiring newfound campus pride or shedding light on previously unknown stories of students marginalized in the school's history. It is also possible that the collections will not be compelling to them, and archivists must try to be aware of these cases. At such times, an archivist's primary task is to foster connections and facilitate student engagement. Ball and Lai stress the importance of "careful attention ... to the selection of local content" that students may find meaningful. ${ }^{40}$ Most college and university archivists are likely discussing with faculty which materials may suit the course content, the intended learning outcomes or skills, and the students' interests. This thoughtful and intentional selection of primary materials-both prior to instruction and in the midst of it-is regular practice for most instructional archivists, and it is significant. The archivist's choices are first steps in leveraging the power of place, positively impacting the students' learning experience, and potentially inspiring positive investment in their local community - their school culture.

Ball and Lai acknowledge another strength of PBE: student-centeredness. They posit that "dialogical negotiation" is the key to strengthening PBE's learning potential for all, and they argue that simply immersing learners in their local environment is not student-centered enough. ${ }^{41}$ Ongoing conversations with students to assess interest, comfort with the materials, and degrees of understanding are critical factors to a studentcentered teaching model. In an archival setting, for example, a discussion to introduce the repository and its mission, along with taking time to learn what knowledge and interests students bring with them can frame the use of Place-Based Education. While the primary sources may be relevant to the students, if students are intimidated by the repository, unsure of how to handle materials, or confused about how the course subject matter relates to their interaction with the resources, the power to leverage those sources may be weakened. Once those obstacles are addressed, the potential of the materials and 
the links that students can make between the past and their own present experiences can be actualized.

Over time, the definition of place and its potential for immersive educational experiences expanded from environmental sciences to encompass the unique art, literature, and performances of communities. ${ }^{42}$ Multiple disciplines can be encountered through the PBE model, independently or concurrently, as real life provides evidence of the inevitable intersection of subject areas. Campus archival collections have a parallel multidisciplinary application. Singular people, events, or subjects can be explored, often at great depth through numerous collections, enhancing course content and supporting extensive research. It is also true that a single primary document can reflect the convergence of a variety of topics or can meet different learning objectives for different classes. For example, an 1820s student letter can provide relevant content for a history of Indiana course studying frontier life; its cross-hatched script and the wax seal on the envelope can provide a material culture course with evidence of the resources available in 1820s Indiana; and an intensive writing course could use it as both an example primary source format as well as inspiration for a reflective writing assignment. A significant number of the students among those different classes are likely to find the learning experience more compelling because they are viewing a letter written by a student living and learning in the same place where they are now. Campus collections are a local institutional resource that provide multidisciplinary learning opportunities.

Ball and Lai's article on the role of PBE in arts and humanities highlights other points salient to the integration of academic archives into the curriculum. They call out the ways in which local art and literature are often subjugated to the more cosmopolitan art of other places, paralleling the privileging of the national and transnational in industry and media. Introducing familiar materials not only makes local content potentially more meaningful, it also provides students opportunities to contribute their voices by identifying their preferences, offering their interpretations, and contributing their perspectives to the "spatial politics of culture." ${ }^{33}$ Similarly, providing students with unmediated primary sources gives them an opportunity to share the unique perspectives and knowledge (i.e., voices) they bring to the evaluation and analysis of those materials. Furthermore, the students' hypotheses, interpretations, and syntheses of primary materials can be made explicit within the context of their roles within the campus community and its history. This provides them with an opportunity to self-reflect about their use of those materials and their agency in creating new primary sources. ${ }^{44}$

A final critique of PBE lies within the context of the digital age. In a 2011 article in the Chronicle of Higher Education, Joseph E. Aoun quotes Bill Gates's 2010 prediction that "place-based activity in college will be five times less important than it is today ... on the Web-for free-you'll be able to find the best lectures in the world. It will be better than any single university." ${ }^{45}$ While online offerings are growing significantly at institutions of higher education across the country, Auon notes the substantial growth of place-based learning as well, particularly through project-based and servicelearning models. He mentions that experiential learning on campus and in surrounding 
communities provides students with advantages that online courses may never be adequately able to provide. In addition, he offers compelling arguments for PBE's ability to provide chance encounters, peer learning environments, exposure to diversity, and "amplified" research opportunities. Aoun concludes, stating that both online and PBE models have a place in higher education, affording students different and unique advantages. Similarly, digital and physical archival collections provide unique advantages. Archives continue to experience the fast growth of collection exposure and of digital access through online finding aids, collection digitization, and digital exhibits. Providing courses with instruction and access related to online resources is an important part of an instructional archivist's job. Recognizing the strengths and limitations of both online learning and place-based learning allows archivists to navigate both, frame pedagogical approaches, better collaborate with instructors, and educate students by using the model(s) that best support their learning objectives.

Each of the aforementioned critiques of PBE is valid, and local primary sources should not be used within a vacuum. Instead, harnessing the power of the local can serve as an easy entry point for students learning to digest primary sources for the first time. Place-Based Education offers numerous advantages, and, ultimately, once students have mastered the concepts within a local context with which they are at least slightly familiar, skills and community contributions are more easily transferable to any place they identify with-from the local to the global.

\section{Case Studies}

In recent years, Indiana University's Archives and its historic Wylie House Museum have worked independently and collaboratively to increase their academic involvement in the campus curriculum. The efforts have been successful, and the use of local campus collections at each repository is a compelling factor in student engagement and enriched learning opportunities. Rather than limiting the scope-of-content study or research opportunity, campus collections provide relevant, meaningful, and accessible materials. The materials embody a legacy of the students' campus community and heritage as well as providing fertile ground for reflection, skill development, creative production, community connection, and new contributions to the institutional narrative.

The collective mission of the University Archives and the Wylie House Museum, both part of the Indiana University Library system, is to "collect, organize, preserve and make accessible records documenting Indiana University's origins and development and the activities and achievements of its officers, faculty, students, alumni and benefactors." ${ }^{46}$ In that capacity, the collection of the University Archives consists of approximately 20,000 cubic feet of records, in addition to 3 million photographic images, films, architectural drawings, and electronic records spanning the university's history from 1820 to the present. Built in 1835 by Andrew Wylie, first president of Indiana University, the Wylie House functions as a historic house museum furnished as it might have looked in the 1840s when the university's first family lived there. In addition to shepherding manuscript and photographic collections, the museum's historic house and 
heirloom gardens offer opportunities for historic interpretation and an active heirloomseed library.

The instruction programs of both repositories have grown dramatically in the past five years to reach a wide swath of departments across the university. In 2017, the University Archives held more than 80 separate sessions reaching over 1,200 students across 20 departments. Similarly, the Wylie House provided 28 course sessions, reaching more than 500 students, spanning 6 departments. Departments served include American Studies, Art History, the School of Business, Central Eurasian Studies, Communication and Culture, Education, English, Folklore, Gender Studies, History, Latino Studies, the Media School, Music, the School of Art and Design, the School of Public Health, Spanish and Portuguese, and Theatre and Drama.

Because of the nature of the collections, each instruction session utilizes primary sources with ties to the local, either through campus spaces or an individual associated with the university, for example:

- Art History A204 East Asian Buddhist Art. Students look at exhibition documentation, photographs, and a film of a Thai art exhibit on campus in 1960.

- Education H340 History of American Education. Students analyze and compare Dr. Wylie's personal correspondence with his professional writings to explore historical empathy and context.

- Folklore F141 Urban Legends. Students analyze variants of common legends such as "The Boyfriend's Death," "The Hook," and "The Babysitter and the Man Upstairs" collected locally by IU students from the 1960s through the 1990s.

- Honors H234 Becoming “American”: Immigration and American Literature. Students examine oral histories of faculty and student immigrants, documentation about historic university programs established to support refugees and international students, and research photographs of Hungarian American communities in Indiana.

- Latino Studies L102 Introduction to Latino/a History. Students look at records documenting the establishment of their department.

- Media School J450 History of Journalism. Students read student humor magazines and short-run newspapers from the alternative press.

- School of Art and Design F340 History of Fashion. Students try to date undated photographs of students on campus based upon design trends they have studied.

- School of Art and Design F402 Historic Textile Management. Students evaluate financial records from the 1800 s to determine available local resources and costs associated with garments.

- School of Public Health O340 Interpretation and Tour Guiding. Students utilize museum-related correspondence and photographs to support interpretation of spaces and objects in the historic house. 


\section{Case Study 1: Wylie House Museum—School of Art and Design F340 History of Fash- ion; Department of Education R398 Culture, Identity, and Rhetoric of Place}

As a small repository with archival collections relating specifically to the 1835 property and the families who resided in the home, Wylie House Museum leverages the advantages of the power of a local campus heritage site and the transferability of primary source literacy skills to broader research projects as well as their integration into historic research and critical analysis skills.

The School of Art and Design's F340 History of Fashion course covers a large swath of history. The nineteenth century comprises only a small component of the course content, but the museum as a local repository, the family's textiles, and the associated primary documents inform inquiries related to broader questions and research methods. The course asks students to consider questions such as, "How do historic styles inform contemporary fashion? Where and how do we access information related to garment design, designers, style, and function? Why is it important for you, as a student of apparel merchandising or fashion design, to be knowledgeable of fashion history?" ${ }^{\prime 47}$ The History of Fashion course asks these overarching questions when using Wylie House primary sources as curricular resources. Initially, Professor Ashley Hasty brought her students to the nineteenth-century museum to view garments in their historical context. Collaborating on a course redesign project with Wylie House Museum, Hasty expanded the learning objectives for the visit to include components of research skills, primary source literacy skills, and critical thinking skills, which she built on throughout the semester to culminate in final research projects.

The focus on a local space was intentional. I wanted to introduce students to spaces and stories that would be relevant to their lives as well as course curriculum. There is a lot of pride at Indiana University and I knew students would enjoy learning more [of] the history of this campus while learning about fashion history. Wylie House allows students to see historic fashion that was worn right here in Bloomington, IN, by people who lived in the house students were standing in and by people who were associated with the university they attend. This provides a stronger connection to course content than a picture online. Eventually, I saw that we could expand upon the visit to provide stronger connections to many course objectives. $^{48}$

Students from Professor Hasty's course read family correspondence and financial records online prior to their visit to the museum. They were asked to reflect on content related to garment making or period fashion, as well as to evaluate the sources for creator, audience, and tone. The class session at the museum exposed the students to the Wylie family's historic garments and the place in which they were made and worn, as well as to the primary sources they first encountered online. Students also handled Wylie family dance cards from nineteenth-century campus dances, precipitating a lively discussion about current campus culture, dress, music, and gender roles. Students in 
campus sororities expressed interest in undertaking further personal research in Wylie House histories and archival collections.

The learning objectives for the visit go beyond simply experiencing the place and the original materials. Students re-evaluate the physical primary sources and compare the interaction to their initial online experience; they then look at transcripts and reflect upon the mediation of artifacts and collections and what is preserved and why, as well as whose records and garments are not available for study. Historical context is discussed, and students are asked to synthesize all that they see and learn into a reflective paper that addresses the three questions posed above. Hasty states, "Not only do they appreciate getting out of the classroom and into local spaces, they begin to experience the types of spaces where their knowledge may be applicable to future careers, such as museums."49 With Place-Based Education at the museum, students establish personal connections to the local past and critically analyze cultural and economic aspects of fashion history and historic interpretation in their own community.

Other courses use Wylie House Museum as a space in which to foster more meaningful learning by connecting Indiana University students with their institutional history. The Department of Education's Culture, Identity and Rhetoric of Place course has been using the Wylie House as an example of a historic preservation project for more than 10 years. Four years ago, Senior Lecturer Cindy Smith redesigned this intensive writing course to use the museum and its primary sources as the subject of the multiple components that build upon each other to form a quality research paper. For example, students read portions of the museum's historic structure report and selected oral histories related to its 1960s restoration. These, in addition to class sessions on the property, contribute to a biography assignment that must incorporate primary and secondary sources, a reflective paper, and a persuasive argument paper related to documented decisions during the reconstruction. These museum-specific assignments serve as a launching pad for more rigorous research on student-selected structures or places for their final research papers. According to Smith,

It is very important to me to anchor what my students are learning about space and architecture to a tangible, local example. Visiting the museum helps students experience the place with all of their senses. Doing so helps them think more critically about changes in architecture through time and the challenges that this creates in interpretation for house museums (real life application). The best possible way to help students make those kind of connections is by "being in the place." ${ }^{0}$

She goes on to say that visiting a physical space helps students recognize surrounding physical and cultural context, important aspects of this course's curriculum. "No place exists in a vacuum, and the easiest way to recognize that is through direct experience." 51 The inclusion of Wylie House visits and research regularly makes an impression on students' final research structure selections. 
A number of students have chosen to focus their projects on historic structures after visiting the Wylie House Museum. One student researched the home she was renting in town. She was able to find local ownership records and historic photographs to complement her research. Another student studied her family's post office and general store through photographs, oral history interviews, newspaper clippings, and even a popular song! Something [emphasis added] about the Wylie House Museum directly sparks their interest in how history connects to their own lives and often inspires extensive inquiry and research. ${ }^{52}$

It seems apparent that the something encompasses and reflects the strengths of PBE. The tangible, evidential primary sources explicitly connected to a place that has at least some contextual relevance to students' experience of Indiana University builds upon those PBE advantages.

\section{Case Study 2: Indiana University Archives - School of Art and Design S485/S582 Metalsmithing and Jervelry Design seminar, Fall 2016 and Spring 2017}

Inspired by the recent acquisition of the papers of Alma Eikerman (innovative metalsmith, jewelry designer, and professor and founder of the jewelry program at Indiana University) in the fall of 2016, the IU Archives paired up with Distinguished Professor Randy Long and Associate Professor Nicole Jacquard of the Metalsmithing and Jewelry Design program in the IU School of Art, Architecture + Design. Seeking to design an assignment relevant to the life of their students, according to Jacquard, the class was "intended to look at the local campus of Bloomington ... and even more specifically Professor Alma Eikerman and her legacy at IU.” For Jacquard (a student of Randy Long, who was a student of Alma Eikerman), it was important that the students in their course understand that they were part of a multigenerational lineage of artists and art educators tracing their roots back to Eikerman. ${ }^{53}$

During the first semester, the 12 students (6 MFA and 6 BFA) were given two assignments. For the first, they were simply assigned to write a research paper focusing on an assigned segment of the Eikerman collection. For example, students looked at Eikerman's travel documentation, her research notes, her correspondence, her teaching files, her photographs, her sketchbooks, and so on. Then they were each assigned to design two pieces of jewelry or hollowware inspired by something they found in the archival collection. According to Jacquard, what the students "found and wrote about was broad and varied and insightful into more of who Professor Eikerman was. This really provided an in-depth background and a wider scope of their placement within the entire project." 54

Ultimately, at the urging of the students, the class turned into a two-semester collaboration. So excited by what they were discovering and creating, the students wanted to find a way to share them with a wider audience. Jacquard and the students submitted 
a proposal to the local Ivy Tech John Waldron Arts Center, and the exhibit Lineage as Legacy: A Tribute to Alma Eikerman and the Metalsmithing and Jewelry Design Area at Indiana University opened in April 2017. Near the entrance, an electronic monitor looped archival photographs of Alma Eikerman as a child, a young art student, a talented artist modeling her work, and an IU professor from 1947 to 1978 (often pictured with her numerous students). On a nearby wall, a "family tree" beginning with Eikerman documented the multigenerational lineage of the student artists represented in the exhibit and, according to Jacquard, "how they are now a part of our family and enduring lineage and legacy." ${ }^{5}$

In terms of artwork represented, some chose to experiment with using new techniques pioneered by Eikerman and documented in her records, while her style influenced others. For example, in Looking Back, Looking Forward, BFA student Angela Caldwell noted that "the piece speaks to her [Eikerman's] affinity for asymmetry and classical metalsmithing techniques combined with contemporary man made materials." ${ }^{56}$ For then third-year MFA student Rose Schlemmer,
Having grown up in the suburbs of Metro Detroit, I was raised around immense amounts of art deco buildings and facilities with an architec- tural grid structure. Upon researching Alma Eikerman, I found a bracelet she created which brought me back to my childhood memories of De- troit. Alma Eikerman's bracelet and my memories led me down a path of interpretation. This interpretation gave me the ability to craft, Recreation, which was directly inspired by the form and dissecting lines in the original bracelet. With the piece, $A$ Version of My Own, I used the same dissecting lines, a similar form, and added hand cut rectangular windows. As a child I thought about the windows in those buildings and what it was like to look out from there. The cutouts are my retrospection of the buildings I constantly saw and adds a part of myself to the bracelet. ${ }^{57}$

The personal connections and life stories found in Eikerman's papers inspired other students. For example, then second-year MFA student Heather Nuber was inspired by the wage-gap issues Eikerman faced as a female faculty member in a male-dominated department. In her exhibit label for Little Pieces, she noted that

Alma Eikerman created statement pieces from simple form and line. She was formidable, but I can imagine she had to be. A single woman, in a male driven field, in male-dominated academia, formidable survives. Although she was a leading force in her field, she fought for decades for equitable pay. Putting myself in her place, I think of all the times she had to smile through back-handed compliments of her "little pieces," as her male counterparts doing "serious" work continued to earn more. I think about her taking all of that frustration out on the metal, and bending it to her will, creating her incredibly influential "little pieces." 58 
In retrospect, while mostly anecdotal, the collaboration was certainly successful from multiple perspectives. It was "one of the best learning experiences the students ever had" according to Long, and Jacquard notes that "I truly believe it gave them a deep sense of place and pride knowing the history that they are now a part of, and will continue to have an effect on." ${ }^{59}$ The process clearly inspired the students, and for those such as Caldwell who until that point usually didn't do research before starting on a new artwork, "the personal relationship of Alma's archives and her connection to IU made the process more interesting." ${ }^{60}$ The collaboration furthered the teaching mission of the Indiana University Archives to reach students across a range of disciplines with primary sources in an authentic way. Furthermore, the resulting Lineage as Legacy exhibit brought the collection to a wider community audience.

\section{Conclusion}

These case studies assist instructional archivists and special collection librarians considering new ways to utilize their collections in the classroom. While these are specific examples influenced by their collection strengths, the possibilities for collaboration with a wide swath of academic disciplines is virtually infinite given the depth and variety found in every archival collection. Archivists working with local collections no doubt instinctually recognize the potential power these materials hold for their students and are regularly attempting to harness it within the classroom. Understanding that these instincts are correct and are founded in long-standing pedagogical theory within archival practice provides greater confidence in teaching.

Place-Based Education offers many advantages. It has the potential to create inspired inquiry and more meaningful learning; however, valid critiques of this method can also be made if archivists assume local resources or campus history compels every student. Archivists regularly work with students who do not see themselves represented in the historical record documented by their academic institutions; thus, archivists must foster meaning, inspire interest, and teach skills rather than relying solely upon the strengths of models such as PBE.

Numerous pedagogical approaches and teaching methods exist. Place-based learning is one tool to add to the toolbox. When appropriate, as shown in these case studies, it can be a strong frame for archivists' collaboration and teaching. When understood as one method among many, and in recognition of its advantages and limitations, archivists teaching in academic settings can consciously and intentionally manipulate PBE and apply it to their instructional advantage across a range of disciplines, ultimately to students' educational benefit. In this way, perhaps archivists are contributing to the Boyer report recommendation to "Cultivate a Sense of Community," which calls for universities "to foster a community of learners" and "create a sense of place." ${ }^{1}$ 


\section{ABOUT THE AUTHORS}

Carey Beam is an assistant librarian and the director of the Indiana University Libraries' Wylie House Museum and Morton C. Bradley, Jr. Education Center. She facilitates the use of the museum's archival and object collections in subjects from a wide variety of disciplines, providing curriculum-based tours, teaching with primary sources, and collaborating with faculty on assignment and course design. Her research is on the academic use and potential of museums of culture and history in higher education. She earned both her MLS and her BA in sociology from Indiana University.

Carrie Schwier is the outreach and public services archivist at the IU Libraries University Archives, where she collaborates with teaching faculty to design and implement primary source-based instruction sessions and assignments. She previously worked as the assistant archivist at the same repository and as a curatorial assistant in the works on paper department of the Eskenazi Museum of Art. She received her MLS from Indiana University and also holds an MA and a BA in art history.

\section{NOTES}

1. Reprinted in Hugh A. Taylor, "Clio in the Raw: Archival Materials and the Teaching of History," American Archivist 35, nos. 3-4 (1972): 317.

2. Peter Carini, "Archivists as Educators: Integrating Primary Sources into the Curriculum," Journal of Archival Organization 7, nos. 1-2 (2009): 41-50; Magia G. Krause, "It Makes History Alive for Them:' The Role of Archivists and Special Collections Librarians in Instructing Undergraduates," The Journal of Academic Librarianship 36, no. 5 (2010): 401-11; Sammie L. Morris, Tamar Chute, and Ellen Swain, "Teaching with Archives: A Guide for Archivists, Librarians, and Educators," in Teaching with Primary Sources, ed. Christopher J. Prom and Lisa Janicke Hinchliffe (Chicago: Society of American Archivists, 2016), 69-136.

3. Elizabeth Yakel and Deborah A. Torres, "AI: Archival Intelligence and User Expertise," American Archivist 66, no. 1 (2003): 51-78; Sharon A. Weiner, Sammie Morris, and Lawrence J. Mykytiuk, "Archival Literacy Competencies for Undergraduate History Majors," American Archivist 78, no. 1 (2015): 154-80; Peter Carini, "Information Literacy for Archives and Special Collections: Defining Outcomes," Portal: Libraries and the Academy 16, no. 1 (2016): 191-206; ACRL SAA/RBMS Task Force on the Development of Guidelines for Primary Source Literacy, Guidelines for Primary Source Literacy—Final Version (Summer 2017), https://www2.archivists.org/sites/all/files/Guidelines\%20 for\%20Primary\%20Souce\%20Literacy\%20-\%20FinalVersion\%20-\%20Summer2017_0.pdf.

4. Wendy M. Duff and Joan M. Cherry, "Archival Orientation for Undergraduate Students: An Exploratory Study of Impact," American Archivist 71, no. 2 (2008): 499-529; Magia Krause, "Undergraduates in the Archives: Using an Assessment Rubric to Measure Learning," American Archivist 73, no. 2 (2010): 507-34; Anne Bahde and Heather Smedberg, "Measuring the Magic: Assessment in the Special Collections and Archives Classroom," RBM: A Journal of Rare Books, Manuscripts, and Cultural Heritage 13, no. 2 (2012): 152-74; Morgan Daniels and Elizabeth Yakel, "Uncovering Impact: The Influence of Archives on Student Learning," Journal of Academic Librarianship 39, no. 5 (2013): 414-22.

5. Barbara Rockenbach, "Archives, Undergraduates, and Inquiry-Based Learning: Case Studies from Yale University Library," American Archivist 74, no. 1 (2011): 297-311; Richard J. Cox, Janet Ceja Alcalá, and Leanne Bowler, "Archival Document Packets: A Teaching Module in Advocacy Training Using the Papers of Governor Dick Thornburgh," American Archivist 75, no. 2 (2012): 371-92; Lindsay Anderberg, "STEM Undergraduates and Archival Instruction: A Case Study at NYU Polytechnic School of Engineering," American Archivist 78, no. 2 (2015): 548-66; Jenny Robb, 
"The Opper Project: Collaborating with Educators to Promote the Use of Editorial Cartoons in the Social Studies Classroom," RBM: A Journal of Rare Books, Manuscripts and Cultural Heritage 10, no. 2 (2009): 70-94; Anne Bahde, "Taking the Show on the Road: Special Collections Instruction in the Campus Classroom," RBM: A Journal of Rare Books, Manuscripts and Cultural Heritage 12, no. 2 (2011): 75-88; Thomas Frusciano, "Bridging Generations: Undergraduate Research Opportunities on the History of Women at Rutgers University," Journal of Archival Organization 1, no. 2 (2002): 77-88; Cory L. Nimer and J. Gordon Daines III, "Teaching Undergraduates to Think Archivally," Journal of Archival Organization 10, no. 1 (2012): 4-44; Anne Bahde,"The History Labs: Integrating Primary Source Literacy Skills into a History Survey Course," Journal of Archival Organization 11, nos. 3-4 (2013): 175-204; Eleanor Mitchell, Peggy Seiden, and Suzy Taraba, eds., Past or Portal? Enhancing Undergraduate Learning through Special Collections and Archives (Chicago: Association of College and Research Libraries, 2012); Anne Bahde, Heather Smedberg, and Mattie Taormina, Using Primary Sources: Hands-on Instructional Exercises (Santa Barbara, CA: Libraries Unlimited [an imprint of ABC-CLIO, LLC], 2014); Kate Theimer, ed., Educational Programs: Innovative Practices for Archives and Special Collections (Lanham, MD: Rowman and Littlefield, 2015).

6. Magia G. Krause, "Learning in the Archives: A Report on Instructional Practices," Journal of Archival Organization 6, no. 4 (2008): 240.

7. Krause, "Learning in the Archives," 240-48.

8. Morris, Chute, and Swain, "Teaching with Archives," 73.

9. Theimer, Introduction, in Educational Programs: Innovative Practices for Archives and Special Collections, vii.

10. Lindsay Anderberg, Robin M. Katz, Shaun Hayes, Alison Stankrauff, Morgen MacIntosh Hodgetts, Josué Hurtado, Abigail Nye, and Ashley Todd-Diaz, "Teaching the Teacher: Primary Source Instruction in American and Canadian Archives Graduate Programs," American Archivist 81, no. 1 (2018): 193.

11. Boyer Commission on Educating Undergraduates in the Research University, Reinventing Undergraduate Education: A Blueprint for America's Research Universities (Stony Brook, NY: State University of New York, 1998), 1.

12. Daniels and Yakel, "Uncovering Impact," 414.

13. David Mazella and Julie Grob, "Collaborations between Faculty and Special Collections Librarians in Inquiry-Driven Classes," Portal: Libraries and the Academy 11, no. 1 (2011): 474.

14. Krause, “It Makes History Alive for Them," 406.

15. Anne Bahde, Smedberg, and Taormina, Introduction, in Using Primary Sources: Hands-On Instructional Exercises, xiv.

16. Boyer Commission, Reinventing Undergraduate Education, 34.

17. Tamar G. Chute, "Selling the College and University Archives: Current Outreach Perspectives," Archival Issues 25, nos. 1-2 (2000): 38.

18. John R. Thelin, "Archives and the Cure for Institutional Amnesia: College and University Saga as Part of the Campus Memory," Journal of Archival Organization 7, nos. 1-2 (2009): 4.

19. Jason G. Speck, "Walking the High Wire: The Impact or Campus Tales and Legends on the University Archivist," Archival Issues 35, no. 2 (2014): 116.

20. Frank Vanclay, Mathew Higgins, and Adam Blackshaw, eds., Making Sense of Place: Exploring Concepts and Expressions of Place through Different Senses and Lenses (Canberra: National Museum of Australia Press, 2008), 3.

21. Jeff Malpas, Place and Experience: A Philosophical Topography (Cambridge: Cambridge University Press, 1999), 2.

22. Ibid.

23. Gregory A. Smith and David Sobel, Place- and Community-based Education in Schools (New York: Routledge, 2010), 23.

24. Gregory A. Smith, "Past, Present, and Future of Place Based Learning," Getting Smart (blog), November 3, 2016, http://www.gettingsmart.com/2016/11/past-present-and-future-of-placebased-learning.

25. Smith, "Past, Present, and Future of Place Based Learning." 
26. David Sobel, Place-Based Education: Connecting Classrooms and Communities, 2nd ed. (Great Barrington, MA: Orion Society, 2005), 3-4.

27. Smith and Sobel, Place- and Community-based Education in Schools.

28. Environmental education was first defined by William Staff (Department of Natural Resource Conservation and Planning at the University of Michigan).

29. David A. Gruenewald, "The Best of Both Worlds: A Critical Pedagogy of Place," Educational Researcher 32, no. 4 (2003): 3-12.

30. Edward S. Casey, Getting Back into Place: Toward a Renewed Understanding of the Place-world (Bloomington: Indiana University Press, 2009).

31. ACRL SAA/RBMS Task Force, Guidelines for Primary Source Literacy.

32. David A. Gruenewald and Gregory A. Smith, Place-Based Education in the Global Age (Hoboken, NJ: Routledge, 2014)

33. John I. Cameron, "Learning Country: A Case Study of Australian Place-responsive Education," in Place-Based Education in the Global Age, ed. Gruenewald and Smith, 284-85.

34. Ibid.

35. Sobel, Place-Based Education, 17-18.

36. Ibid., 34-59.

37. Eric L. Ball and Alice Lai, "Place-Based Pedagogy for the Arts and Humanities," Pedagogy 6, no. 2 (2006), 261-87

38. John Dewey, "The Child and the Curriculum," in John Dewey on Education: Selected Writings, ed. R. D. Archambault (Chicago: University of Chicago Press, 1902), 352-53.

39. Ball and Lai, "Place-Based Pedagogy for the Arts and Humanities," 268.

40. Ibid., 271.

41. Ibid., 273.

42. Casey, Getting Back into Place: Toward a Renewed Understanding of the Place-world.

43. Ball and Lai, "Place-Based Pedagogy for the Arts and Humanities," 280.

44. ACRL SAA/RBMS Task Force, Guidelines for Primary Source Literacy, Analytical Concepts section.

45. Joseph E. Aoun, "Learning Today: The Lasting Value of Place," Chronicle of Higher Education 57, no. 36 (2011).

46. Indiana University Bloomington, "University Archives," https://libraries.indiana.edu/archives.

47. Ashley Hasty, "F340 History of Fashion Syllabus," January 9, 2018.

48. Hasty, e-mail to author, April 24, 2018.

49. Ibid.

50. Cindy Smith, e-mail to author, April 24, 2018.

51. Ibid.

52. Ibid.

53. Nicole Jacquard, e-mail to author, April 23, 2018.

54. Ibid.

55. Nicole Jacquard, quoted in Julia Lee Barclay-Morton, "IU Professor's Archives Inspire CrossDiscipline Projects,” Library Journal, August 23, 2017, https://1j.libraryjournal.com/2017/08/ academic-libraries/iu-professors-archives-inspire-cross-discipline-projects/\#_.

56. Angela Caldwell, exhibit label for Looking Forward, Looking Back, from the exhibit Lineage as Legacy: A Tribute to Alma Eikerman and the Metalsmithing and Jewelry Design Area at Indiana University, April 29-May 20, 2017.

57. Rose Schlemmer, exhibit label for Recreation and A Version of My Own, from the exhibit Lineage as Legacy.

58. Heather Nuber, exhibit label for Little Pieces, from the exhibit Lineage as Legacy.

59. Randy Long, quoted in Barclay-Morton, "IU Professor's Archives Inspire Cross-Discipline Projects."

60. Angela Caldwell, quoted in Barclay-Morton, "IU Professor's Archives Inspire Cross-Discipline Projects."

61. Boyer Commission, Reinventing Undergraduate Education, 34. 